\title{
The Occurrence of Problematic Behaviour in the School Environment
}

\author{
Gabriela Gabrhelová ${ }^{1}$, Lenka Pasternáková ${ }^{2}$, Dáša Porubčanová ${ }^{3}$ \\ ${ }^{I}$ DTI University, Department of Didactics of Specialized Subjects, Sládkovičova 533/20, Dubnica nad Váhom, Slovakia \\ ${ }^{2}$ University of Prešov, Faculty of Humanities and Natural Sciences, Street of. 17. th Novembr 15, \\ Prě̌ov, Slovakia \\ ${ }^{3}$ DTI University Department of School Didactics, Sládkovičova 533/20, Dubnica nad Váhom, Slovakia
}

\begin{abstract}
Nowadays, aggression and bullying are serious societal problems present in all types and level of schools. It is an extremely complicated system that can be examined from many different angles. This is a dangerous social-pathological effect where personal freedom is severely restricted, it is degrading human dignity, and often harming the victims' health or property. For these reasons, we decided to focus our attention on the issues of manifestations of aggression and the possibilities of its elimination.
\end{abstract}

Keywords - school environment, secondary school, problem behaviour, prevention

\section{Introduction}

In the school environment, undesirable behaviour associated with aggression occurs very often. According to experts, aggression is a manifestation of aggressiveness and it is considered an offensive or militant form of behaviour, a manifestation of hostility towards a certain object, a deliberate attack on an obstacle, or a person on the way to satisfying a need. Aggression belongs to social-pathological phenomena, which have been elaborated in several publications not only by foreign experts but also by experts from Slovakia.

DOI: $10.18421 /$ SAR32-02

https://doi.org/10.18421/SAR31-02

Corresponding author: Dáša Porubčanová,

DTI University, Slovakia.

Email: porubcanova@dti.sk

Received: 17 May 2020.

Revised: 14 June 2020.

Accepted: 20 June 2020.

Published: 30 June 2020.

(cc) BY-Nc-ND (C) 2020 Gabriela Gabrhelová, Lenka Pasternáková \& Dáša Porubčanová; published by UIKTEN. This work is licensed under the Creative Commons Attribution-NonCommercial-NoDerivs 3.0 License.

The article is published with Open Access at www.sarjournal.com
Teachers, school counsellors, school and counselling psychologists, and social workers are daily

witnessing students' violence aimed against students, objects but also teachers in schools.

\section{Definition of Aggression and Terminological Research}

By most experts, aggression is considered a form of behaviour aimed at harming others. According to Bordens and Horowitz [2], a person who deliberately hurt and harmed another person or another living organism or object is described as an aggressive person. Authors divide the types of aggression differently. In their research, experts - researchers work with hidden and apparent aggression, as well as proactive and reactive aggression. They also mention symbolic aggression, relational aggression and the like [3], [8]. Of these, we will be most interested in physical and relational aggression. Zahatňanská [11] defines aggression as hostility, manifestations of aggressiveness or explosiveness in the behaviour of a certain subject, attacking an obstacle on the way towards satisfying a need. She distinguishes between four levels of aggression: a) without an external manifestation - it only takes place in one's thoughts; (b) manifested externally, e.g. slur; c) destruction; manifested by door slamming, smashing objects, etc. (d) physical assault of another person.

Aggression denotes the current manifestation of this behaviour [9]. We can say that every person has an innate disposition to aggressive behaviour, but the propensity for such behaviour is not dependent only on heredity, as it develops by learning but also under the influence of the environment. The society's tolerance towards aggression and aggressive behaviour has changed over time and it is constantly changing - the social climate can trivialize aggression and can also indirectly support it. Concerning the analysed issue, it is also important to mention hostility. In general, hostility is understood as an attempt to harm someone, it is a negative attitude towards another person, respectively to people in 
general. It may form the background for aggression, but may not result in it.

A very close and correlative term concerning aggression is the concept of bullying. Bullying - in each of its forms - is a specific type of aggression. According to most experts, bullying means deliberate and repeated harming, the enslavement of the victim, in which there is an evident disparity of power between the aggressor and the victim.

The results of a comprehensive study on the conditions and the causes of aggression in secondary school students showed that an important role is played by several interacting factors stemming from the personality of the aggressor and the victim, as well as from external situations and environments.

An individual's psyche is an important source of causes and circumstances that can stimulate or trigger aggressive behaviour. According to Oravcová [6], there are two basic groups of internal factors of aggression: (a) factors related to the personal disposition of an individual; (b) intermediary processes in the personality of the individual.

The personality background of aggression is individually distinguished depending on the personality disposition of the individual. Therefore, different people can react differently in the same situation based on their personality traits. The disposition background of aggression consists mainly of relatively stable personality characteristics of an individual formed during their development and include the following factors: (a) innate factors that a human brings to the world (biological determination). Each person has certain dispositions for aggressive behaviour. The majority of the population is prone to moderate aggression; in this case, there should be only a few deviations. The innate predispositions for aggressive behaviour include the following: characteristics of the functioning of the nervous system, such as prevalence of excitement over attenuation, rapid activation of some parts of the brain, which are now identified as controlling aggressive behaviour; heredity - most experts agree that aggression is partially inherited; characteristics of an individual's biochemical processes, e.g. different blood composition and also increased sensitivity to aggressive stimulation - high blood alcohol content, low sugar, high testosterone (male hormone), decreased serotonin metabolism; some personality traits, e.g. temperament, impulsivity; characteristics related to structural but also functional changes in the brain; the impact of gender and age - male hormone testosterone leads to a greater degree of aggressiveness in boys than girls. Testosterone levels increase significantly during adolescence when more aggressive manifestations occur; learned patterns of behaviour - in this case, aggressive behaviour can be a learned expression, a pattern that gradually becomes a permanent part of its reactivity in the process of individual development. A child will adopt aggressive behaviour patterns, especially if he/she grows up in an environment where aggressive behaviour is rewarded, where it has become a common norm for behaviour that the child imitates, with which he/she identifies, even unwillingly. The adoption of such behaviour also takes place when a child finds out that the use of instrumental aggression is worthwhile, beneficial, leads to the achievement of his/her objectives.

According to Šip [10], each situation requires a person to be prepared, ready, and willing to do something. The activation level changes situationally. In general, the likelihood of aggressive behaviour increases with the increasing activation level. The activation status increases the way people perceive situations, as well as external circumstances. In this case, even a completely neutral stimulus (a child's question addressed to his/her father who is watching a film) can be perceived as hostile and aggressive and cause an aggressive reaction. Different people interpret and evaluate situations based on different criteria - it is the cognitive processing of the situation. In the case of incentives provoking possible aggression, people interpret mainly the intention of the initiator. In reality, however, it is only their perception and interpretation of the intention. The decisive factor is not whether the person has enemy intentions, but whether we perceive them as such. An incorrect cognitive handling of a situation increases the likelihood of inappropriate, aggressive behaviour. The most common social-pathological theories are based on the presumption that there are structural deficiencies in the society, which affect its members differently, not equally. Children and adolescents are the most endangered groups by these effects, because, in addition to seeking their own identity, they naturally have an increased curiosity, want to try something new, have a strong desire for unusual experiences and adventures, they need to overcome social shyness and mildness, find their place in the social space. In order to help children and young people overcome this risk period, there is a need to talk about certain measures that we call prevention or preventive measures for the occurrence of socialpathological behaviour [1].

The social environment surrounds individuals during their entire lives and the primary educational institutions - family, school, social and cultural institutions - have an impact on them. Individuals learn to live in this environment, to respond to stimuli coming from this environment and to manage the situations, which social life brings. Experts point out that the social environment can stimulate 
aggression on the one hand (e.g. neo-fascist groups whose violence is often manifested) and, on the other hand, to suppress aggression (e.g. prevention programs carried out by educational, cultural-social and edifying organizations). The prerequisite for satisfying the basic needs of children in terms of their protection against threats, abuse, aggression and bullying (physical and mental) is the creation of favourable internal and external conditions by both parents and their children.

At the same time, the family represents a very intimate environment, which may complicate the efforts to penetrate to the essence of its interactions (between parents and children, siblings, husband and wife), way of upbringing, the level of corporal punishment, the nature of requirements placed on children and the family climate.

Methods of investigating aggression and bullying may overlap in specific school conditions with strategies of regression measures against detected violence. In this case, their application can be based on a cooperation between the school and families. According to Kolár [5], two basic methods have proven to be practical: a) the reconciliation method; (b) the external pressure method.

The method of reconciliation is less frequent and used in dealing with cases in the early (non-brutal) stages of aggression and bullying (or - in the case of younger aggressors - in primary and lower secondary schools). It is not based on punishment, but a common and controlled search for redress in the informal atmosphere of the educational group. It includes a series of social exercises under the guidance of a counselling psychologist or a social worker aiming to transform the internal group relationships and to practice assertive behaviour. The method of external coercion is the most common method used by teachers and educators in cooperation with students' parents in practice against aggression. A system of sanctions and penalties is used to stop aggressive behaviour and adherence to standards adopted by the society. The method emphasizes the protection of the group as a whole but takes less account of the preventive-educational needs of individuals. Its application includes the following stages:

1. Making the decision whether it is necessary to report such an event to the police. It depends on the intensity, method, and the consequences of aggression and bullying;

2. An individual or commission interview with the victims, aggressors, and their parents (after the investigation), during which they are informed about the results of the investigation and the proposed sanctions and measures (e.g. transfer to another school, conditional exclusion, a proposal for a lower behavioural grade, stay in a diagnostic centre for youth, etc.)

3. Informing the educational group (class) about the decision to punish the aggressor with an educational effect (convicting an act, not a person);

4. Summoning other students' parents and informing them about the incident and its resolution;

5. Emphasizing to other students that what happened is also the responsibility of those who did not immediately report the manifestations of aggression and bullying or did not interfere.

6. Protection of the victim by more intensive monitoring, regular cooperation with parents, appointing protectors amongst the classmates or from the close surroundings of the school, etc.

7. Evaluation of the incident and taking appropriate measures by the teaching staff to reduce the possibility of repeated aggression [6].

By giving a punishment, however, the whole affair closes and its actors get a chance to start a new life further punishment, remorse, shouting or constant reminders of guilt can provoke resistance and defensive reactions. Above all, it is necessary to condemn the act, not the person, and to give students an opportunity to redress. For one act, we impose one punishment in cooperation with all educators and the family. In practice, the aggressor is often punished for the same act at school, then at home or at the school dormitory, which does not give him/her many chances, enthusiasm or mental powers to change. If we find out that some educational measures are less effective or their application does not bring a positive change, we must replace them operatively after some time. The effect is given by a well-defined criminal record for a certain defined manifestation of unwanted behaviour that everyone is familiar with.

According to Říčan [7], and Holá and Hanuliaková [4], in some situations, both the pedagogical staff and the parents often make the following mistakes in detecting and tackling aggression and bullying in students: When they suddenly reveal the aggressive behaviour they witness, they often try to investigate what happened immediately, directly in the classroom, in the educational group, in the street or in the yard, and they ask individual students about what happened; they investigate the victim together with the aggressor; they believe false claims by false witnesses influenced by the aggressor; they disregard the trauma and the victims feelings of guilt, which makes them unable to speak about the aggression the victims are often silent, denied, even afraid that the aggressor is a friend; they often make an immediate confrontation of the victim's testimony with that of the aggressor without verifying what has happened by several credible witnesses; they do not 
take into account the fact that there is often an addiction between the victim and the aggressor, the victim can even identify with the aggressor; they solve the problem by letting the victim leave or transfer to another class or school, but the problem remains not resolved and is far from being over; they do not realize that aggression can infect the whole class (school) and do not investigate into the stage of aggressive behaviour; educators can even make such a fatal mistake that the victim is declared an aggressor.

\section{Research Method}

Most research focus on analysing the state and the causes of aggression from the perspective of students themselves. Frequently, research is focused on the following problems:

1. What are the experiences of teachers with aggression in schools?

2. What are the attitudes of teachers towards students' aggression at school?

3. How is the occurrence of aggression among students dealt with?

Based on the above, we conducted a research aimed at analysing the incidence of aggressive behaviour in 84 students in the first year of their studies at secondary vocational schools in Slovakia. We made a comparison of aggression among students of the majority and the students from socially disadvantaged environments.

Based on the obtained results, the data were interpreted and also presented in tables indicating statistically significant differences. In the interpretation of the research results, we only present statistically significant differences.

During the research, observations were carried out, based on which we ascertained the significance of differences related to the manifestations of aggression among students of the majority and students from socially disadvantaged environments.
Table 1. Significance of differences related to manifestations of students' aggression

\begin{tabular}{|l|r|r|r|}
\hline \multicolumn{1}{|c|}{ Questions } & $\begin{array}{c}\text { Respondents } \\
\text { of majority }\end{array}$ & $\begin{array}{c}\text { Respondents } \\
\text { from socially } \\
\text { disadvantaged } \\
\text { backgrounds }\end{array}$ & $\begin{array}{c}\text { Mann- } \\
\text { Whitneyov } \\
\text { U test }\end{array}$ \\
\hline Defamation & 2,57 & 2,45 & 0,01 \\
\hline Persiflage & 1,77 & 4,11 & $4,66 * *$ \\
\hline Ignorance & 0,57 & 1,34 & $2,61 * *$ \\
\hline Verbal attacks, threats & 3,05 & 6,77 & $3,70 * *$ \\
\hline Gun intimidation & 0 & 0 & 0 \\
\hline Stealing things & 0,31 & 1,68 & $4,63 * *$ \\
\hline Destruction and smash & 0,42 & 2 & $4,83 * *$ \\
\hline Things & 0,11 & 0,54 & $2,17 * *$ \\
\hline Hiding things & 0,11 & 0,74 & $2,83 * *$ \\
\hline $\begin{array}{l}\text { Forced and undignified } \\
\text { behavior }\end{array}$ & 0,25 & & 0 \\
\hline Forced and degrading \\
consumption
\end{tabular}

\section{Research Findings}

Based on the observations, in the context of verbal aggression among the respondents in the first year of their studies, there were statistically significant differences in the answers regarding "mocking", "ignoring", "verbal attacks, threats" in favour of the respondents from socially disadvantaged backgrounds. In the case of "defamation", which is part of the observation sheet, there were no statistically significant differences. As for other categories of observation - "stealing things", "depreciating and destroying things", "hiding things", there were also statistically significant differences between the responses of majority students and the respondents from socially disadvantaged backgrounds. Statistically significant differences were found in favour of freshmen from socially disadvantaged environments in the item focusing on "forced and undignified behaviour". 
During the observations made, statistically significant differences occurred in "physical harm" and "degrading acts and touches" in favour of the respondents from socially disadvantaged backgrounds. There were also statistically significant differences in identifying the aggressors in the class in favour of these respondents. Students and a group of aggressive students in the observed first grades came from socially disadvantaged environments.

Table 2. The significance of the differences between the measured values regarding the reasons for the aggression prevailing among students

\begin{tabular}{|l|r|r|r|}
\hline \multicolumn{1}{|c|}{ Questions } & $\begin{array}{c}\text { Respondents } \\
\text { of majority }\end{array}$ & $\begin{array}{c}\text { Respondents } \\
\text { from socially } \\
\text { disadvantaged } \\
\text { backgrounds }\end{array}$ & $\begin{array}{c}\text { Mann- } \\
\text { Whitneyov } \\
\text { U test }\end{array}$ \\
\hline Jealousy & 0,57 & 1,25 & $2,86 * *$ \\
\hline $\begin{array}{l}\text { The desire to hurt } \\
\text { others }\end{array}$ & 0,31 & 1,51 & $4,66 * *$ \\
\hline $\begin{array}{l}\text { The attempt to } \\
\text { succeed }\end{array}$ & 3,67 & 3,57 & 0,25 \\
\hline The desire for power & 1,4 & 1,71 & 0,58 \\
\hline $\begin{array}{l}\text { Dealing with own } \\
\text { complexes }\end{array}$ & 0,4 & 1,54 & $3,84 * *$ \\
\hline $\begin{array}{l}\text { The effort to attract } \\
\text { attention }\end{array}$ & 3,37 & 4,62 & $2,28 * *$ \\
\hline $\begin{array}{l}\text { Congenital aggressor } \\
\text { tendencies }\end{array}$ & 0,68 & 1,82 & $3,19 * *$ \\
\hline $\begin{array}{l}\text { The aggressor's } \\
\text { emotional immaturity }\end{array}$ & 0 & & \\
\hline Others & 0 & 0 & 0 \\
\hline
\end{tabular}

Throughout the observations, we also wanted to find out about the attitudes towards aggression among the participating students. The respondents indicated that they often "have fun of it", that they "admire aggressors" or "are among the actors". In these items, there were statistically significant differences in favour of the respondents from socially disadvantaged backgrounds. Throughout the observations, we tried to find out which reasons led the respondents to aggressive behaviour. Based on the observation scheme, which was created for this purpose, we can conclude that our respondents were led to aggression by "jealousy", "a desire to hurt others", "dealing with their complexes", "trying to attract attention" and "the inborn tendencies of the aggressor". For these reasons, there were statistically significant differences in favour of the respondents from socially disadvantaged backgrounds.

In the context of the analysed issues, in our view, an effective prevention against any adverse manifestations of aggression is linked to the requirement that parents should accept and love their children as they are, regardless of their appearance, intellect, abilities; they should communicate with the children, talk to them about their school experiences or friends, their needs, values; pay attention to their children, care about their problems, worries, and joys; help them build healthy self-confidence provide them with appraisal and appreciation, but also with healthy criticism; determine the children's borders, constraints, what they can and cannot do; they should lay down certain rules which give children security, provide guidance, and control them; to manage their behaviour, emotions, control themselves in expressing negative feelings (anger, hatred, rage, etc.) and realize that anger and aggression are the results of their own failure and can become a model for solving conflicts.

\section{Conclusions}

The current trend of today is to be aware of own rights. This means that even children and young people have their rights. However, it is important to bear in mind that having rights also means taking responsibility for violating the rights of others, and this responsibility should be considered by both children and young people. As a result of promoting democracy and humanity, they have taken freedom for granted. The role of family and schools is to lead them to decent behaviour. School climate research has shown that students in schools lack empathy, and there is a lot of aggression and bullying in schools. In conclusion, we can assume that aggression and bullying are serious social problems. They can occur in any form and have a destructive impact on the formation of the human personality.

\section{Acknowledgement}

The contribution was created as the outcome of the project "Strategies to support adherence of students to the rules in the educational environment" Project no. 005DTI-4 / 2018th

\section{References}

[1]. Barnová, S., Tamášová, V., \& Krásna, S. (2019). The role of resilience in coping with negative parental behaviour. Acta Educationis Generalis, 9(2), 93-106.

[2]. Bordens, K. S., \& Horowitz, I. A. (2014). Social psychology (4th ed.). Solon, OH: Academic Media Solutions.

[3]. Crick, N. R., \& Grotpeter, J. K. (1995). Relational aggression, gender, and social-psychological adjustment. Child development, 66(3), 710-722.

[4]. Holla, K., \& Hanuliakova, J. (2017). Social Positions Of Students And Cyberbullying. Ad Alta: Journal of Interdisciplinary Research, 7(1), 52-57.

[5]. Kolár, M. (1997). The hidden world of bullying in schools. Prague: Portál.

[6]. Oravcová, J. (2004). Social pathology. Banská Bystrica: FHPV UMB. 
[7]. Říčan, P. (1995). Aggression and bullying among children. Prague: Portál.

[8]. Swit, C., \& McMaugh, A. (2012). Relational aggression and prosocial behaviours in Australian preschool children. Australasian Journal of Early Childhood, 37(3), 30-34.

[9]. Tirpák, P. (2016). Socio-pedagogical starting points in favour of human development. Acta educationis 3843.
[10]. Sip, M. (2016). Socio-pathological effect in a family with a child with special educational needs. When we think family... Kraków: Uniwersytet Papieski Jana Pawla II w Krakowie, 2016, 227.

[11]. Zahatňanská, M. (2018). Adolescence as a risk of problematic behaviour. Quality of life and responsible-low-risk behaviour. Košice: Technical University of Košice, 2018, 69. 